\title{
MODELS OF PROFESSIONAL EMPLOYMENT OF THE GRADUATES OF BRNO MUSEOLOGY IN CULTURAL INSTITUTIONS
}

\section{LUCIE JAGOŠOVÁ - OTAKAR KIRSCH}

\section{ABSTRACT/ABSTRAKT:}

The successful implementation of study disciplines at universities is closely linked with the continuous revising and modulating of study curricula that should reflect both the development of theory in a particular discipline and the specialist requirements of practice, as well as the verification of the graduates' employment. These trends can be studied, among other things, on the museology and museography branches of tertiary education. The article, centred on museum studies at Masaryk University, Brno, presents the concept and conclusions of combined research carried out in $2016 / 2017$ as a follow-up to curriculum changes. It analyses the influence of the study of museology in Brno on the professional careers of the graduates of one year of distance learning, how it affected their lives and shaped their careers.

Modely profesního uplatnění absolventů brněnské muzeologie v kulturních institucích

S uspokojivou realizací univerzitních studijních oborů úzce souvisí průběžné revize a remodulace kurikula studia, odpovídající vývoji oborové teorie i odborným požadavkům praxe, a ověřování uplatnění vlastních absolventů. To můžeme sledovat také na muzeologických a muzeografických oborech terciárního vzdělávání. Článek, zaměřený na obor muzeologie na brněnské Masarykově univerzitě, představuje koncept a závěry smíšené výzkumné sondy realizované 2016/2017 v návaznosti na předchozí kurikulární změny. Sleduje, jaký vliv mělo studium muzeologie v Brně na profesní dráhu jejích absolventů - jednoho ročníku dálkového studia - za jakých okolností vstoupilo do jejich života a jaké dopady vneslo do jejich kariéry.

\section{KEY WORDS/ KLÍČOVÁ SLOVA:}

museology - university teaching Brno - graduates - professional employment - research muzeologie - univerzitní výuka Brno - absolventi - profesní uplatnění - výzkumné šetření

\section{PROLOGUE: (Self-)evaluation as a mirror of the university programmes of museology/ museum studies}

In order to qualify as an autonomous scientific discipline, museology has to develop and elaborate its own theory (subject of study, methods, terminology, infrastructure), as well as to aim at practical application in the life of society. At this level, the main objective of museology (with regard to the fact that a distinct proportion of museums' theoretical output focuses on the museum as an institution and on museum work techniques) is the professionalization of museum work which often leans on intuitive, random and practiceoriented concepts rather than on technical and theoretical museum findings. For the dissemination and adoption of museological findings museology education is crucial, including the platform of professional museum organisations, the study of the production of publications and journals, the organisation of conferences, seminars and workshops. A key role in the systematic development of museology is played by academic institutions with a high potential, even for those who do not work in this field.

Nowadays, museum institutions are found on all continents. Problems currently discussed involve their hypertrophy and clashing approaches in the definition of disciplines such as "museum studies" (practical) and "study in museology" (theoretical). ${ }^{1}$ The reflection of different approaches to these studies - their concept, quality and impact on graduates holds up a mirror to these branches, resulting in feedback that can be used in the revision of the curriculum and that will, beyond doubt, affect the professional

\footnotetext{
1 In the context of German-speaking countries see e.g. WALZ, Markus. Theory and Praxeology of Museology: On the Current Ascendancy of Special Museologies in Germany. Museologica Brunensia [online]. 2015, vol. 4, no. 2, pp. 20-27 [cit. 2017-02-02]. Available from www: <https://digilib.phil.muni.cz/ bitstream/handle/11222.digilib/134744/2_ MuseologicaBrunensia_4-2015-2_6. pdf? sequence $=1>$.
} 
careers of the graduates of these studies.

Research and self-evaluation studies can be obtained, in different forms, from a large number of academic institutions. For example, a questionnaire survey in Berlin conducted by Petra Helck, Editha Schubert and Ellen Riewe (Hochschule für Technik und Wirtschaft Berlin, 2005) ${ }^{2}$ focused on the graduates' employment in cultural and memory institutions. Of 57 respondents participating in the research ${ }^{3}$ who studied in the school in the years 1993-1999, over half now work in culture. 18 graduates work in museums, 14 in archives, art institutions, libraries and art shops. Another example is a questionnaire survey in Leipzig (Hochschule für Technik, Wirtschaft und Kultur Leipzig) centred on graduates from the years 2000-2004 and their practical employment. Of 42 respondents, 22 now work in museums, 9 outside the museum sphere, 5 were still studying and 6 were unemployed. ${ }^{4}$ The third selected example is a Brno study (Masaryk University Brno, 1997) by Vinoš Sofka and Suzanne Nash devoted to the reflection of a decade of museology courses organised by the International Summer School of Museology (ISSOM) in Brno. ${ }^{5}$

2 HELCK, Petra SCHUBERT, Editha and Ellen RIEWE. Absolventenbefragung des Studiengangs Museumskunde an der Fachhochschule für Technik und Wirtschaft Berlin. Berlin: Institut für Museumskunde, Staatliche Museen zu Berlin Preußischer Kulturbesitz, 2005.

3 The authors got back $48 \%$ of the questionnaires (117 graduates in total were approached).

4 The authors got back $61.8 \%$ of the questionnaires ( 42 persons out of 68 responded). See Ist Museologie eine "brotlose" Kunst? Wie sehen die Arbeitsmarktchancen für Absolventinnen, Absolventen de

Museologiestudiums aus? In Hochschule für Technik, Wirtschaft und Kultur Leipzig, Fakultät Medien [online]. Last revision 15. 5. 2014 [cit. 2017-05-02]. Available from www: $<$ http://www. fbm.htwk-leipzig.de/index.php?id=9178 > .

5 Archive of DAM, Centre of Museology (unsystemized), file ISSOM Study Report of Courses on General Museology 1987-1996. SOFKA, Vinoš and Suzanne NASH. Ten years
This questionnaire survey involved both the course lecturers (in ten years, there were 67, with 26 Czech or Slovak) and participants (in ten years, elementary course A saw 145 participants, of whom 14 took part in follow-up ISSOM courses). The analysis focused on the teaching programme in summer, lecturers (countries, lecture topics) and participants (numbers, countries, institutions) and on the evaluation of teaching by the participants.

The revision of the study curriculum and the verification of the graduates' employment can be, apart from the mentioned examples, also presumed at other universities and their museology (museography) branches. In some cases, however, these are unpublished research studies, which can be logically explained by some highly personal and sometimes even negative findings that the branches keep as unpublished material strictly for their internal use. This article enters this frail environment and presents the results of the authors' own research in 2016/2017 into the influence and impact of study on the professional careers of the graduates of one year of distance learning of museology at Masaryk University in Brno. The impact of the study of museology seen through the graduates' eyes is observed in the context of individual professional careers and their transformations over ten years, before the start, in the course of and after their university studies of museology, until the present.

of courses on General Museology and the International Summer School of Museology at Masaryk University 1987-1996: Analytical study. Directory of lecturers and participants. Participants' replies to questionnaires (Brno: Masaryk University, UNESCO Chair of Museology and the World Heritage, 1997).

\section{The teaching of museology at Masaryk University in Brno - revision, modulation, reflection}

Brno museology counts among the traditional and the oldest academic museology centres in the world. ${ }^{6}$ In the development of its academic teaching started in the 1920s it followed the form of its predecessor, the Lectorate in Museum Studies, ${ }^{7}$ with postgraduate teaching of museology introduced in the 1960s educating Czech and Slovak experts from museum practice, ${ }^{8}$ until the third,

6 On the general development of the branch at universities see e.g. LORENTE, Jesús Pedro. The development of museum studies in universities: from technical training to critical museology. Museum management and curatorship [online]. 2012, vol. 27, no. 3, pp. 237-252 [cit. 2017-02-02]. Available from www: $<$ http://www.academia. edu/1846608/The development of museum studies_in_universities_from_technical_training_to_ critical_museology $>$

7 The Lectorate in Museum Studies was established at Masaryk University in the 1920s, headed by Jaroslav Helfert, the follower of the Vienna school of art and design and director of the Moravian Museum. Regular lectures (virtually every term) continued until the 1950s, except during the war. Theo were intended for regular students of disciplines such as history and history of art, whose future employment in museums was expected, in regard to the shortage of experts with university education in museum practice. Helfert accentuated in his teaching concept, using the close connection between university and practical teaching in the Moravian Museum, the need for theory and expertise, and the courses included, for example, The Conception and Tasks of Museology and Tasks of Museum Administration in Educating Future Museologists and in Practice. For more information see KIRSCH, Otakar and Lucie JAGOŠOVÁ. Vývoj Lektorátu muzejnictví 1922-1951. Devadesát let od počátků univerzitního vzdělávání muzejníků v českých zemích. Muzeum: muzejní a vlastivědná práce, 2013, vol. 51, no. 1, pp. 3-16.

8 A key shift from the teaching of museum theory towards museology was represented by the External Department of Museology (later the Centre of Museology), the establishment of which in the 1960s is credited to luminaries such as Jan Jelínek, director of the Moravian Museum, who lent shape to the activities of the International Council of Museums (ICOM), and Zbyněk Z. Stránský, a leading figure in museology theory with his own concept of the field and its teaching. Postgraduate study launched in 1963 was intended for workers and experts in museums, and aimed to make museums more professional. The interest in postgraduate study shifted, on the threshold of the new millennium, towards the newly introduced possibility of studying museology as a regular branch of study. On the subject see e. g. STRÁNSKÝ, Zbyněk Z. Brno: education in museology: on the 10. anniversary of the foundation of the museological department of the Philos. fac. of the J. E. Purkyně University 
current form of the organisation of study. The change of the political situation in the early 1990s brought the establishment of a regular study programme, later also distance learning, ${ }^{9}$ in a two-stage cycle of bachelor and master studies.

The development of the museology curriculum ${ }^{10}$ in the past fifty years corresponds to the continuously revised concept in accordance with the definition of the discipline by Zbyněk Z. Stránský and his associates and followers ${ }^{11}$ and the reflection of trends in museology

in Brno. Brno: J. E. Purkyně University, 1974 RUTAR, Václav. Vznik, vývoj a práce externí katedry muzeologie v Brně v letech 1963-1969. Museologica Brunensia [online]. 2014, vol. 3, no. 2, pp. 4-11 [cit. 2017-02-02]. Available from www: <https://digilib.phil.muni.cz/ bitstream/handle/11222.digilib/133106/2 MuseologicaBrunensia_3-2014-2_3. pdf? sequence $=1>$; KIRSCH, Otakar.

Vysokoškolská výuka muzeologie v Brně v době normalizace a nástupu demokratického režimu. Museologica Brunensia [online]. 2014, vol. 3, no. 2, pp. 12-20 [cit. 2017-02-02]. Available from www: < https://digilib.phil.muni.cz/ bitstream/handle/11222.digilib/133107/2 MuseologicaBrunensia 3-2014-2 4.

pdf? sequence $=1>$.

9 The development of museology at Masaryk University in Brno is analysed in several texts, see note 8 . The most recent articles in English include a special issue on this subject of the Museologica Brunensia periodical 2016/2, centred on Zbyněk Z. Stránský, the key figure in Brno museology.

10 The structure of the subjects taught in the individual decades is conveyed by the article MRÁZOVÁ, Lenka and Lucie JAGOŠOVÁ.

Contentual changes in the curriculum of the Brno Chair of Museology in 1964-2014. In UNESCO Chair of Museology and World Heritage [online]. [cit. 2017-05-02]. Available from www: <http:// www.phil.muni.cz/wune/home/publikace/clanky/ view?set_language $=\mathrm{en}>$.

11 See e. g. MÜLLER-STRATEN, Christian. The contribution of Zbyněk Stránský to museology and contribution of the Brno museology school. In Muzealizace $v$ soudobé společnosti a poslání muzeologie/Musealization in contemporary society and role of museology: Sborník ze sympozia s mezinárodní účastí pořádaného při príležitosti životního jubilea tvưrce brněnské muzeologické školy Zbyňka Z. Stránského/Anthology from symposium with foreign participation in the occasion of anniversary of the founder of the Brno museology school Zbyněk Z. Stránský. Praha: Asociace muzeí a galerií České republiky, 2008, pp. 27-35; MRÁZOVÁ, Lenka. Remarks on the role of Z. Z. Stránský in conceptual development of the curriculum of Brno museology. Museologica Brunensia [online]. 2016, vol. 5, no. 2, pp. 65-73 [cit. 2017-02-02]. Available from www: <https://digilib.phil.muni.cz/ bitstream/handle/11222.digilib/136265/2_ MuseologicaBrunensia 5-2016-2 9.

pdf? sequence $=1>$. and museum practice. Another activity worth mentioning is meetings of museology lecturers, ${ }^{12}$ whose input was reflected in the curriculum and in the approach to the individual courses in the past. Also, the previous small numbers of graduates in the era of postgraduate museology studies enabled a natural overview of museology institutions and the graduates' employment in practice, which is impossible now, given the current state of affairs. After extensive remissions of the Brno museology curriculum in 2014 in both cycles, another logical step appears to be research that would provide at least a partial insight into the professional histories of the former students.

\section{The impact of the study of museology on the professional careers of the graduates. The story of one year of combined study of museology in Brno}

The concept of research carried out in 2016/2017 related to curriculum changes took the form of survey observing the influence of the study of museology in Brno on the professional careers of the graduates: how it was reflected in their lives and what impact it had on their careers. The basic characteristics and results acquired presented in the following section, will hopefully stimulate a discussion on the development of approaches to teaching, its limits and suitable corrections in future. The Survey Design (Chapter 3.1) follows two subsequent lines. The overall interpretation of data for all respondents (Chapter 3.2) is followed by the creation of basic professional models for the graduates based on the individual

12 MRÁZOVÁ, Lenka and Lucie JAGOŠOVÁ. Contentual changes in the curriculum of the Brno Chair of Museology in 1964-2014. In UNESCO Chair of Museology and World Heritage [online]. [cit. 2017-05-02]. Available from www:<http:// www.phil.muni.cz/wune/home/publikace/clanky/ view?set_language $=e n>$. professional and personal stories of the graduates, with the objective to identify the common features of these individual stories (Chapter 3.3).

\subsection{Survey Design}

The opening section about the research gives brief characteristics of the project, describes the manner of data collection and assessment, and it also points out their limits that might have influenced the implementation of the survey.

Research into the influence of study on the professional careers of the graduates sought to test (or to search for common features and tell stories), ${ }^{13}$ against the backdrop of over fifteen years of the respondents' professional careers, in what manner and with what impacts (under what circumstances and with what motivations and goals) museology and its study entered their lives, and how (with regard to the circumstances of the respondents' personal/private lives and their life situations at the time when they started to study museology) it shaped the focus of study and the profession/discipline during the study and after its finishing, and how it affected their further career development. Research approached in this way could thus only centre on the investigation of the practical employment of the former extramural students

13 Two main and four elaborating research questions were defined. The main questions: Q1: What are the impacts of the study of museology on the professional careers of the graduates? Q2: How has the respondents' relationship to museology and museum practice developed over the past 15 years? Elaborating questions: q1: In what stage of their professional career and under what circumstances did the respondents decide to study museology? q2: How do the graduates assess the study of museology and what benefits does (museum/work) practice bring them? q3: How do the respondents use the knowledge in the field and specialist competence acquired during the study in their lives (professional, study or personal)? q4: How do the respondents work on their further education and professional growth in museology? 
(combined study, in-service study) of museology at the Faculty of Arts, Masaryk University, Brno. The research further focused on one selected study year ${ }^{14}$ whose students completed their bachelor and master programmes approximately within the last five years. All the respondents were students that, through the date of their matriculation, belonged in the mentioned year in the bachelor and/or master study programme.

The design of the planned research can be characterised as a combined one, working with a small research group, with the use of both quantitative and qualitative approaches and a combined form of their evaluation. It employed data acquired by a questionnaire survey, document analysis and personal interviews. ${ }^{15}$ The research observed three basic lines: work, study and personal paths of the respondents. ${ }^{16}$

14 Our ambition was to select respondents (most of whom had graduated by then) in the middle of their professional careers, with whom further professional steps after the graduation in museology could be identified, at least partially. For a successful implementation of the project, it was necessary to select a distance-study year whose students have maintained contacts with the university department, as well as with one another, i.e. a sample with the highest potential for acquiring the highest number of respondents in a relatively small basic group.

15 To select a particular study year, the following procedure was applied: 1) the checking of

data from the Information System of Masaryk University containing the basic data of students and e-mail contacts, information about the completion/failure to complete/interrupting of the study of museology, etc. - see Masaryk University Information System [online]. [cit. 2017-

-02-02]. Available from www: <https://is.muni. $\mathrm{cz} /$ ?lang $=\mathrm{en}>$; 2) selection of a particular year and the acquisition of the necessary e-mail contacts (Information System of Masaryk

University, contacts of the graduates); 3)

construction and collection of data from the e-questionnaire (in google docs) and the collection of further groundwork and information from the respondents of both written and verbal characte (e.g. individual explanatory and written materials for the $\mathrm{k} \mathrm{e}$-questionnaire, e-mail correspondence, non-structured and semi-structured personal interviews). The preparation and execution of the research took place in June-December 2016 (data collection), with continuous assessment from October 2016 and the collection of additional information and data interpretation in the first quarter of 2017

16 The work line traces the development of the professional careers of the graduates before, in

the course of and after their studies of museology;
In the implementation of the research it was necessary to take into account its limits. These included the small number of respondents dictated by the set research design and the basic research group of one year, and the related manner of the possible evaluation of data, as well as difficulties in contacting and engaging the graduates, ${ }^{17}$ the course of research and the collection of data affected by the researchers themselves; they are the former teachers of the respondents, which might have influenced the course and results of the survey. ${ }^{18}$ The survey used the acquired data to put together and tell the stories of the graduates of distance learning ${ }^{19}$ of museology in Brno in one year. The interpretation of data discussed further in the article focused on the summary of the results for the observed year (in chronological terms, from the period before the study, in the moment of the decision to study museology, with the studies. The personal line focuses on the identification data about the respondents an personal overlaps that affected the employment and the course of study of the respondents, with regard to their life situation when they started to study. The study line observes the motives for the study, its course, felt benefits and negatives and the impacts of the study on professional and personal life.

17 It lies in the difficult sustainability of contacts for former students, owing to regular changes of workplaces or the graduates' work outside the field. It is also necessary to take into account a limited further interest in the field or in the faculty after the completion of the studies.

18 The fact that the researchers were also the respondents' former teachers might have played a part in the willingness or a lack of it to take part in the research, as well as in the extent of openness when answering the questions and in the form of final statements. An important part was played by the "delicacy" of the respondents' task to assess their own studies or branch. There was also the risk of unfavourable findings and the readiness to publicize the results of the research regardless of their positive or negative tone towards the researchers' workplace.

19 The authors are aware of the differences that would have been manifested in the study of regular students, as opposed to extramural students. The selected distance-learning group was preferred because of the already formed careers of these respondents, which would not have been possible with the graduates of the regular study programme. its course, impacts and current reflection) and on the derivation of basic models of the graduates' individual stories that share some common features. Due to the small research sample, the authors list in the data interpretation the actual numbers of the occurrence of the answers given, not their percentages.

\subsection{The influence of the study of museology on the professional careers of the graduates. Research results and their interpretation}

The research centred on a selected year of distance learning (the year is not specified, in order to ensure the respondents' anonymity) where the basic group in the bachelor programme included 20 students (13 women and 7 men), 9 of whom continued to study museology in the master programme and 6 did not complete their bachelor studies (i.e. by the time of the survey evaluation). 17 people (11 women and 6 men) continued to study in the following year of the master programme; one person failed to complete the studies. ${ }^{20}$ The final group of respondents involved in the research by filling in an e-questionnaire consisted of 18 people (12 women and 6 men).

\subsubsection{Yes to the study of museology. Professional and personal lives of the respondents in the course of the previous decade and in the moment of commencing the study}

In the particular year, we observed respondents whose paths in relation to the development of their professional careers in 10 years before the study

\footnotetext{
20 In contrast, some students in the original bachelor programme who did not finish their studies within the set period of time but in an extended one, or those who interrupted their studies might now be considering the following master programme.
} 
of museology until its actual beginning distinctly varied. The observed group included people whose professional lives devoted to museology in the given decade saw no major changes (lasting interest in museology, unchanged professional positions). However, there were also respondents who in the given decade changed their job positions in the sphere of museology and culture in general, either in their work activities (i.e. working in different positions in museums, museum methodology centres, the National Heritage Institute, information and cultural centres) or study. ${ }^{21}$ The last group is characterised by temporary or continuous employment before the study in completely different areas - e. g. marketing, fashion industry or self-employed. The total of 12 respondents state work "in the field" in the period before the study of museology and at its beginning. The respondents enrolled for the study chiefly from work (12), while on maternity leave (3), straight from previous studies

(2) or as disabled/senior citizens (1). Most of them (9) started to study museology at the age of $26-35,4$ at the age of 36-45. Two respondents were in the age category $18-25$ and one in the category 46-55. One respondent was in the 56 plus category.

The respondents' life situations in the period of making their decision about the university study of museology varied. They reflected the respondents' lives in general and their satisfaction in relation to their age, status, work situation and lifestyle. Their starting points at the beginning of their studies thus differed considerably. Some respondents were single and without obligations or lived with partners or spouses, some

21 It concerned the relevant previous (degrees of) focu of study followed by looking for work in the field. lived in a kind of vacuum state triggering a need for a change and new stimuli or for a personal development in their field. Others were motivated to study by the possibility of new employment (e. g. a felt need to change specialization or profession or to move forward in the existing profession, or to develop their skills outside their profession), by the time potential of the period for study (e. g. mothers on maternity leave) or by a compensation of a difficult period in their lives (serious illness in the family, a complicated relationship).

While disclosing the individual motivations for study, several factors working in parallel emerged. The majority of the respondents wanted to fulfil their ambition to acquire a university degree (11) and to promote their specialist and professional development (10) and career growth (7), both external (employer, family) and internal (a motivation to acquire university education and thus also professional development). 6 respondents were motivated to a career restart by a newly chosen branch of study, for 2 respondents the study meant an escape from their current life situation. There were also other reasons that the respondents (4) chose not to specify. From the attitudes of their employers, 4 respondents felt interest and support in their studies, 6 felt a lack of interest on the part of their employers but had their support, and with 3 respondents the employers' attitude signified both a lack of interest and lack of support. Other variants were described by 5 respondents. This group possibly included respondents on maternity leave, the disabled/senior citizens, as well as those that had not been employed yet.

\subsubsection{The study of museology and its course}

In the next part of the interpretation we will focus on the respondents' view of the studied subject and the circumstances under which they began their studies. The study of museology in Brno was started by respondents with different types and degrees of education, or with combinations of formal and further education. Secondary education was achieved by 9 respondents, but almost all of them began their university studies with a time gap after the completion of a secondary school. Some respondents emphasized achieving better qualifications, which indicates museum workers (as well as professionals) or persons working in related positions (selfgoverning bodies, information centres), for many of them, a university degree was important for career growth - mostly in museums but also in professions outside the field (firefighter). Vocational education was achieved by 4 respondents with the ambition of career and professional growth (restorer, conservator), but also for the knowledge of museum functioning or a professional restart (after maternity leave) or working in a completely different profession (rescuer). 7 respondents started the study of museology with a university degree, again for a professional restart or professional and career growth (gaining the position of museum director / work in museum management). Other types of study (courses) were mentioned by 3 respondents, mostly with secondary education who thus advanced from non-academic to academic education.

The respondents explained their choice to study museology at the Centre of Museology in Brno by several reasons. An important though not the main - factor was 
the time and place accessibility

(9) and the related easy access from their workplaces, or local patriotism. Nonetheless, a number of respondents came from more distant locations (České Budějovice, Mariánské Lázně, Liberec). ${ }^{22}$ The interest in the discipline of museology was given by 13 respondents, while for 8 the most important part was played by the connection between the discipline and their work position. For 9 respondents, the prestige of Brno university and/ or the department was crucial, ${ }^{23}$ and 4 respondents enrolled on the basis of recommendation. Other reasons were given by two respondents, ${ }^{24}$ and one explained the choice by the low demands of the study. ${ }^{25}$

Naturally, the quality of teaching influences the perception of the discipline, as well as the willingness to introduce and apply the acquired knowledge in practice, and thus also the possibility of influencing other prospective students. In the perception of the

22 There are three key centres of museology and museography in the Czech Republic. Besides Brno, these include Opava (university teaching specializing in museum conservation) and Prague (the absence of university teaching in the field is partly offset by museum propedeutics, an unofficial course of non-formal education for museum workers, organized by the Association of Museums and Galleries of the Czech Republic) Brno is available not only to students from the surrounding area (easy obtaining of study leave, patriotism), but also in terms of public transport accessibility for applicants from locations more remote than Opava.

23 Masaryk University counts among the most important and traditional universities in the Czech Republic, not only according to the specialist public (in contrast to small and newly established universities). Although museology is a traditional discipline, the applicants can also learn about it and be motivated to study it by the influence of teachers at vocational schools and courses of museum propedeutics.

24 A part can be also played by the different focus of study at Opava university which specializes in conservation and heritage care. 25 This can be explained by the complexity of the distance form of study for those studying and working at the same time and when they also look after their families, parents, houses, etc. Any felt easiness of study in the field is rarely communicated openly, due to the small group and the easy identification of the respondents. quality of teaching, a prominent role is played not only by education (including the balance between theory and practice, excursions) but also by personal approaches of teachers and by fellow students these create a personal motivation and a more favourable view on the quality of teaching. When assessing this issue, one has to take into account a possible distortion of the results acquired. ${ }^{26}$ According to these results, 10 respondents assessed the teaching at the Brno Centre of Museology as highquality, while 6 persons viewed it as overall quality teaching. According to 2 respondents, the teaching was average, and no respondents saw the teaching as low-quality or bad.

The perception of the discipline by respondents can be also affected, apart from their inner motivation to study, by the successful completion or, in contrast, failure to complete studies; however, even those less successful assessed the teaching and their relation to museology generally positively. In the observed group, 13 respondents completed the studies in the master programme, and their assessment of the discipline was more positive. The bachelor programme was successfully completed by 3 respondents who did not continue in the master programme. 2 respondents failed to complete the bachelor programme (in one case, the respondent with a university degree gave up the study of museology due to

\footnotetext{
26 In the case of interest in emailing the results of the survey, the respondents could write in the anonymous questionnaire a contact e-mail address, which might have affected the degree of openness of their communication. Overall, we can see a slightly better rating with older graduates. From past experience in distance learning, this can be interpreted by the fact that people with longer working experience are more appreciative of the study because they know the difficulties and pitfalls of self-study. The comments show the valuation of practice-oriented courses. We can speculate about the high demands of theory- and history-oriented courses (with the necessary knowledge of facts and context).
}

a demanding job position). No respondent failed to complete the study in the master programme. ${ }^{27}$

\subsection{3 "Post-museology" period. Impacts of the study of museology after the completion of university education through the eyes of the respondents}

In the area of the impact of the study of museology, we focus first on assessing the personal benefits, restrictions and losses that the former students note from their point of view in hindsight. Benefits included the achievement of values such as education, a broader orientation in the subject, university degree, verification of one's ability to achieve a goal, a good team and lasting contacts with fellow students and educators, the possibility to find a job and the relationship to Brno. On the other hand, the study of museology limited the respondents' free time, finances, or took away their illusions about the functioning of study administration, complicated their family life, raised self-doubt and affected the faith in the ability to successfully complete the study, and caused temporary difficulties in combining work and study duties.

The extent and intensity of the graduates' relations with the Centre of Museology in Brno after the completion of their studies varies as well. The observed year included personalities shaping practice in the field both locally and regionally. 6 respondents did not maintain contact, yet they did not exclude their possible resuming. ${ }^{28}$ 4 respondents who currently do not

27 This can be explained by the good orientation of the students in the study system, the requirements of the teachers and the good prediction of how successfully they meet the demands of the study.

28 These respondents only have indirect contact with the Centre of Museology through their former fellow students from the year who they meet regularly. 
maintain contact (explained e. g. by the distance of their workplace or by limited work possibilities) did not rule out future collaboration with the Centre of Museology. In contrast, occasional or regular contacts or interest in information about the Centre of Museology were given by 8 respondents. Those working in the field use the opportunity of meetings within seminars and conferences, and some directly participate in the events organised by the Centre of Museology open to the graduates and the specialist public (e. g. lectures, excursions) and follow the publishing activities of the teachers and students (e. g. theses). The highest level of collaboration involves the graduates as opponents of theses, they also collaborate on publishing activities, work as external lecturers at the Centre of Museology, etc.

The respondents themselves consider contacts with museum practice (through teaching, excursions, study trips, when writing theses) ${ }^{29}$ the main benefit of the study of museology for (museum) practice, along with the possibility of employing museology competence and contacts in their profession. ${ }^{30}$

\footnotetext{
29 It helped create a general overview in the field and of gaining knowledge and professional contacts, including part of the respondents working in a different sphere and partly also "newcomers in the field". Long-term workers in the field emphasised in-depth knowledge, a view from a different perspective, expanded personal contacts that could be used in their working life, testing of new procedures or activities from the individual areas of museum work (from conservation to museum exhibition criticism) and instant application of knowledge in their museum work. The "novices" in museum practice appreciated the study of museology as an impetus for deciding on the further course of their life (arousing of interest in museology and impetus for changing their work position in order to work in museum practice).

30 The respondents indicate the possibility of engaging in realized projects and their practical outcomes, studying as an aid in specializing in a particular area of museology, appreciating the development of contacts with fellow students who remain in the field, as well as the use of the acquired contacts in specialized and foreign institutions. Also, thanks to the study they
}

The question whether the museology study had benefits that influenced the graduates' professional career and what they were brought a whole spectrum of answers. The answer yes is related to new employment (new position in the museum), promotion at work, new professional qualities for the existing profession or museum work as such, the establishment of external cooperation, change of specialization to work outside the museum (due to the family situation and time requirements of museum work), or the personal contribution of the study in general (refinement of thinking, improvement in written presentation, improvement of skills). Among the negatives, the respondents mention the fact that the use of knowledge beyond the scope of their own occupation (museum) is perceived as unwelcome by the management, or that there is no interest in the use of new knowledge. For part of the respondents, the study of museology had no effect (it did not affect their professional activity) or no positive influence, as a new view on museum work gained by the study brought them disillusionment concerning the gap between the ideal state and reality.

Whether the teaching has impacted permanently or not, whether it is anchored in their current work - this is also related to the further qualification development and the perceived need for further education in the field. ${ }^{31}$

\footnotetext{
specialized and decided about their further direction in practice. Furthermore, they feel a better awareness of inter-professional overlaps in museum work, although some of the findings are not directly used by the respondents because of their profession. Those outside the field stated that they did not use the acquired competence and contacts.

31 i.e. whether and to what extent the graduates feel, after the completion of their tertiary

education, the need to be in touch with the field of study by attending conferences, lectures, through self-study and the study of literature, membership in professional organisations, and attending other courses.
}

A significant proportion of the respondents does not confirm this after the completion of university studies (no - 12, yes - 6), for a variety of reasons; ${ }^{32}$ the lack of the respondents' interest was not represented. Concerning the respondents' ambitions to develop further in the area of museology / museums, most of the answers were positive (14), some respondents (3) were not decided (mostly they are no longer active in the field), one gave a negative response.

- information acquired during the study can be used in the respondent's current job in a museum

- in the field of PC technology, contacts for specialized and foreign institutions

\section{What changes in their career paths from the moment of graduation until now do the respondents feel? ${ }^{33}$ Some respondents are not aware of any significant changes. Those who do state how a change occurred (from a volunteer to an employee of a museum, a change of employer in the same job position, as well as cases of getting a new job after graduation or the possibility to work in museology; another respondent refers to the broadening of employment opportunities), or how it might affect their career path through its equalisation}

\footnotetext{
32 They work outside the sphere of cultural institutions; on the other hand, workers in museums may have a problem at work if they have a different job position (e.g. technical positions), and the employer might be reluctant to give them permission to take part in study activities. Only some of the events are related to museology - they concern museum pedagogy, public lectures at the Faculty of Arts of Masaryk University, and exhibition courses organised by the Association of Museums and Galleries of the Czech Republic.

33 Due to various extensions or interruptions between the bachelor and the master programmes, the period that has passed since the end of the study varies with the individual respondents some finished several years ago, others, for example, only in the last two years, and one respondent is still completing the master's degree.
} 
potential ${ }^{34}$ in the future. However, the study of museology does not only lead to career development; some respondents decided to leave their jobs or the area of museology. ${ }^{35}$

With their professional plans and ambitions for the future, part of the respondents aim to maintain their current jobs, or intend to further develop in the field, ${ }^{36}$ to educate themselves ${ }^{37}$ or to pass on the acquired knowledge and experience. There was also the idea of finding a job in the museum ${ }^{38}$ or, in contrast, leaving the museum (in favour of work in civil service, outside the area of culture). Some respondents say they have no clear idea for the future.

Some respondents (7) added, beyond the questionnaire framework, opinions important from their point of view. These concerned the felt need for standardized museology education for museum workers, ${ }^{39}$ a retrospective view of the studies and attitudes towards the field of

\footnotetext{
34 The respondent views the master's degree as a "reserve" for the future - as a possibility of future employment in case of a serious illness, when he is physically no longer able to do his current job.

35 One of the respondents states that due to the study, they realized that the existing job positions does not allow them further professional growth, and thus changed both the employer and work orientation

36 e.g. goals to open museums more to the public or to implement a particular large project.

37 Interest in further study of museology or in specialization in a particular area or a museological discipline.

38 Until now, the respondent has not worked in a museum despite their interest, which explains the worries about inadequate practice and, in particular, the impossibility of combining work in a museum with the family situation, perhaps financially. Another respondent is interested in getting a specific job in a museum (museum educator)

39 "Do you think that every museum employee should have a degree in museology? YES, because if this were the case, I' $m$ convinced that it would make a big difference to museums."

"Although the study of museology already has its tradition, many people have no idea that this field can be studied. And some people who work in museums consider the study of museology unnecessary."
}

museology as such, as well as the support of the relationship between the department and its graduates.

\subsection{Models of professional employment of the graduates of Brno museology. Personal stories of the respondents}

When analysing the questionnaire survey data and other documents from the respondents, as well as personal interviews, the general analysis of the observed year as a whole brought to light specific stories. Looking at the common features of these individual stories, which through the eyes of the respondents uncover the effects of the study of museology on their personal and professional careers, four distinct models emerge. ${ }^{40}$ We attach a particular story of a respondent to each of them, along with their brief characteristics. ${ }^{41}$

\subsection{1 "Museology for expertise"}

The first identified professional model is the professional story of a museum worker who, at a certain moment in their long-term practice, decides to pursue a university degree in museology. The motivation to study museology in this group of respondents is based on the ambition of strengthening their professional competence in a particular area or in the specific position in which the respondent operates - without wanting to

\footnotetext{
40 Based on the analysis of data from the individual respondents, common features of the graduates' stories and resulting professional models were identified. For each professional model, a specific story was selected reflecting information from the e-questionnaire and written and verbal information about the respondents and from the respondents (in the extent and depth the respondents agreed to share).

41 In order to preserve the anonymity of the respondents, we use fictitious names when presenting them and leave out the names of institutions, places and other markers that might disclose the identity of the respondents to the local expert community. On the other hand, the sex, age and the summaries of the key moments in the respondents' personal and professional careers are authentic. Answers cited verbatim are given
} in italics. change the work position or discipline. They want a stable career and self-improvement, adequate education, professional development and a gradual shift towards expertise.

\section{The first story: Joseph (36-45 years)}

He had worked for thirteen years as a director of a municipal museum. He enrolled to study museology from work, already had a university degree in a technical field and had attended museology courses. He chose to study museology in Brno due to his interest in the discipline, its relation to his work position and the prestige of the department/ university. The main impetus for his decision to study museology was the effort to professionally restart and promote his career growth. It was his own decision without the assessment of the employer's attitudes towards his study (he is only liable to the town council). Suitable conditions for his study were provided by family and friends who were also the main boost for him to complete the studies. He does not comment on what the study gave him and what it took away.

He graduated with a master's degree. There have been no changes in his professional career since. Similarly, in terms of career plans and ambitions for the future, he hopes that no changes will occur.

His relationship with museology and museums before the graduation, after it and now has been positive, and he also assesses his study year and interpersonal relations in a similar way. Among the benefits of the contact with museum practice during his studies, even though he has longterm work experience, he mentions contacts with other museum 
workers, making basic documents for the museum and the related area. In his own words, he uses the acquired museological competence and contacts constantly, and his ambition is to further expand his knowledge in museology and about museums.

After his museology graduation in Brno he did not take part in any other courses because of the long distance from his workplace, and does not maintain regular contacts with the Centre of Museology in Brno.

\subsection{2 "Museology for pleasure"}

Typical examples of the second model are stories of people outside the field of museology, e. g. mothers on maternity leave. The study of museology was triggered by personal (non-professional) interest in the field or a way to effectively use time for selfeducation. Another reason may be the need to compensate or balance work outside the sphere of cultural institutions or the feeling of a stereotype. The intention to concentrate immediately or in the future on museums or cultural institutions generally applies only to a part of the respondents. For some, museology as a discipline or its study is a kind of hobby, relaxation, and the study brought them personal development and pleasure. However, this does not necessarily mean that they pursue the discipline and develop in it.

The second story: Victoria (26-35 years)

She enrolled to study museology from her maternity leave, with the ambition to earn a university degree and promote her career growth. Her previous education was vocational. She was motivated to study by the need for personal development through university studies, not by focusing on a field in which she would seek to find a job after the end of her maternity leave ("I only felt the need to develop further, and thanks to the reconsideration of my attitude towards the branch (I gave up the idea that I would have to work in the field that I studied) and I eventually decided for museology."). She decided to study museology in Brno due to her interest in the field of museology, as well as for time and local accessibility.

During her studies her maternity leave ended and she returned to the previous position of a fashion shop manager that was considerably different from the field studied.

The study duties of a mother with small children, trying to combine her studies with the running of the household and later on returning to work and with her workload, proved to be very challenging ("Because of the complications I myself caused, my studies caused problems in my marriage, I was burdened financially by the study fees and it brought me a lot of self-doubt and frustration about my abilities, yet I never doubted whether to finish or not, and I am still convinced of its benefits."). The main stimulus for completing the bachelor programme was her personal engagement. Appropriate conditions for study were also created by her fellow students with whom she had a good relationship. Professionally, only the change of employer has been made since the completion of the bachelor programme ("Basically no changes, only a change of employer, same position; I refuse some offers for family reasons."). In spite of the organisational difficulty of the study, she decided to persist and continue with post-graduate studies that she is currently engaged in. Her decision to continue in the master course had two reasons - primarily "the understanding of university studies only being complete with the master's degree. The second factor was the change in the concept of study and its distinct orientation on museum pedagogy."

She sees the existing contact with museum practice established during the study as the expanding of horizons and appreciates important personal contacts. Although she does not currently use her museology competence and contacts in the field because she does not work in it, she appreciates the development of general competence that she can develop through her studies ("Studying at university certainly improved my skills, focusing on problems, writing, refined my thinking. At least I hope so.").

Her professional plans and ambitions for the future do include a professional change, but she has not yet found courage to work in the field ("...to abandon the career in retail business, but I certainly can' $t$ devote myself to museology (lack of practice)."). She has the ambition of further expanding her knowledge in museology. Due to her current active studies, owing to which she maintains regular contact with the Centre of Museology, she does not take part in other courses or lectures in the field.

\subsection{3 "Museology as a professional restart"}

The third group of graduates' stories goes hand in hand with the change of career path - an ambition to retrain in a new field, and to try for a new job position as an educated and qualified expert. As shown by the professional models of the graduates of the year under study, it is never too late to make such a change, whether one 
has previous experience in working in cultural institutions or not.

\section{The third story: Hannah (56+)}

At the time of her enrolment, she just started her retirement and longed for a new work-related activity. Prior to the retirement, she had worked for 35 years in the civil service, and for the last 7 years was in a senior position in a municipal museum. She began to study at the time of her retirement, and now, as a senior citizen, she works as an administrator in the museum that she had managed before.

Her ambition to study was motivated by a change in her life situation and by the possible acquiring of a university degree, but her employer at the time showed a lack of interest and support for her intention to study museology. During her studies she used her contacts with museum practice - she gained insight into the field and made necessary contacts; and she still benefits from the information and contacts obtained during the study period. After finishing her studies three years ago, she advanced to the position of the museum administrator; her current ambition is to cooperate on the preparation and implementation of a project of new spaces and an exhibition in the museum and the centralization of archaeological finds with local links, which are located in other institutions and are essential for the history of her town.

She studied museology as a secondary school graduate and after completing courses on museology. She chose to study museology in Brno for local and time availability and for her specific interest to study museology. Suitable conditions for the study were provided by her family and friends, fellow students and educators. She successfully completed her studies at Brno museology with a bachelor's degree and also in the following master programme. The main reason for the completion of studies was the acquiring of a university degree.

She did not attend any further courses, workshops or lectures, and is currently not decided whether she wants to further expand her education in museology. She is not currently in contact with the museology department. (She remarks: "It would be good to be in 'in the picture' and maintain contacts with the ex-students, although it is very demanding.") Her relationship to museology has remained stable before and during the studies and after graduation, and she refers to it as positive.

\subsection{4 "Museology as disillusionment from museum practice"}

The fourth identified model presents a group of respondents with continuous (long-term jobs, a great deal of work done) employment in museums, where dissatisfaction with the processes in the functioning of the museum institution is gradually seeping in. The moment in life and a professional impulse/ change in the form of the study of museology brought to this group of respondents tension in the form of the contradiction between the state taught at university and the mundane museum reality in their everyday practice. Unless the respondents are in a position to reduce the dissonance between what is expected and the reality, they lose their last hopes and illusions of their ability to influence the practice in their museum institutions and the associated internal processes, or the practice in the field as such, which the respondents solve by loosening or unbinding the ties with their home institutions.

\section{The fourth story: Tony (46-55 years)}

Prior to the start of his studies, he had worked for over ten years as a collection manager in a specialized museum in a large town; five years before the commencement of the study, besides the function of curator he had also been the administrator of the museum complex. His employer requested that, on the basis of relevant legislation, he completed his education ("I tried twice to study the branch of archive studies at Charles University in Prague, but unsuccessfully, because it could not (in time or otherwise) be combined with work in the museum."). Before starting his studies in Brno, he had attended the Museum Propedeutics Course, organised by the Association of Museums and Galleries of the Czech Republic. He decided to study museology in Brno with regard to time and local availability, his interest in the field and also on the basis of recommendations. At the time of beginning his studies, he was working as the administrator of museum collections. During his studies, however, he did not see any interest or support from his employer ("In the case of my superior, perhaps I could mention support when I was allowed to use my study leave to travel to Brno for consultations.").

During his studies, the organisation of distance learning was crucial for him ("As far as the teaching is concerned, I learned, of course, many new things, from history as well as about conservation, presentations, work with the public and others. However I would particularly like to emphasise and praise the way the 'combined' study in Brno is organised."). Although he had gained enough experience in the field during his long career, 
the studies gave him the impetus to test new practices. ("In fact, I have had enough contact with 'museum practice' for over twentyfive years of work in the museum [...] (and similar institutions). During my study practice, I was able to try new procedures, be it museum criticism or the preparation of an exhibition, especially later on, on the anniversary of Brno museology. During excursions I visited places where I had not been, but also a number of those I knew from the past. When writing both my theses, I could (at last) devote myself to a subject that really interests me, and there was also an opportunity to combine archive research with the processing of three-dimensional collections."). The study which he completed by obtaining a master's degree had given him the ability to look at museums and museology from a different angle than as an employee of an institution. In the end, however, this paradoxically led to the decision to end his career in the institution and to leave the job ("I would not say that I gained some museological competence through the study of museology, but I can say with certainty it convinced me to leave the curator position [ ...] in the museum, which I finally did. [...] I thus could not make any use of any knowledge from my studies... It is true, however, that after my departure (August 2013), three people held the collections curator position in the museum over a very short period."). He is now self-employed and devotes himself to what was the subject of his interest and profiling in the specialized museum. He maintains regular contact with the Centre of Museology with which he cooperates, and remains faithful to the field of museology ("You forgot to ask if after all and with what I know today I would go into museology again. The answer is Yes, of course!"). He intends to pass on the acquired knowledge and skills, and he also lectures.
The above characterized professional models appear to be separate and incompatible, yet the opposite is true. Apart from the listed examples of four specific professional stories of the graduates, we can also find in the monitored year stories of respondents who experienced their combinations. The big advantage of the observed year is the graduates' closeness, thanks to which they were able to support and motivate each other during their studies, and their need for regular meetings did not end after graduation. Also, the respondents from this year were more than willing to share their personal stories with the authors and let them inspect the different ways in which museology affected their professional development.

\section{THE EPILOGUE}

There exists a number of ways in which university departments can gain feedback on their curriculum, the organisation of teaching, or on the impact on the learners who studied there, and information about their employment in practice and impact on the further development of the field.

Based on data gathered in 2016 and 2017 among the former students from one year of distance learning, the Centre of Museology had an opportunity to view a possible influence of the study of museology at Masaryk University in Brno on the careers of its graduates, as viewed by themselves. Although this was only a fraction of respondents from the existing number of graduates in this field of study, the results of this combined research bring interesting stimuli and uncover a fairly varied range of individual stories. They stimulate thoughts about the motivation to study, the evolving relationship with the field and the impact of the study that marked the career paths and personal life of the graduates.

One of the major conclusions of this small survey is the realization that the study of museology is a ticket to career growth in the field only for a part of extramural students working at the same time in practice, in museums or other cultural institutions. Even previous long-standing practice in a museum does not necessarily mean that there will not later occur some professional or life changes diverting the graduates from work in museums. There are huge differences in the conditions and customs of the individual institutions employing the students, and in some of them there is still a wide gap between theory (expected optimum) and museum practice (the real state), as well as differences between museum institutions in perceiving the importance of the study of museology and its relevance to museum practice. However, the study of museology can also bring or support the determination to start in the field in various life stages, be it in leisure time (or as compensation for a job in which one cannot fully develop, or an area that is not fulfilling) or application in a new profession. This clearly shows the need for a well-designed curriculum that will ensure professional and personal development of future graduates from different walks of life, from a "recreational" interest in museology related to leisure time to the fulfilment of high demands of museum workers and museologists with ambitions at expertise.

\section{SOURCES:}

Archive of DAM, Centre of Museology (Department of Archaeology and Museology, Faculty of Arts, Masaryk 
University, Brno, Czech Republic) (unsystemized).

HELCK, Petra, Editha SCHUBERT and Ellen RIEWE. Absolventenbefragung des Studiengangs Museumskunde an der Fachhochschule für Technik und Wirtschaft Berlin. Berlin: Institut für Museumskunde, Staatliche Museen zu Berlin - Preußischer Kulturbesitz, 2005. 167 p. Mitteilungen und Berichte aus dem Institut für Museumskunde, no. 34. ISSN 1436-4166.

Ist Museologie eine „brotlose“ Kunst? Wie sehen die Arbeitsmarktchancen für Absolventinnen, Absolventen des Museologiestudiums aus? In Hochschule für Technik, Wirtschaft und Kultur Leipzig, Fakultät Medien [online]. Last revision 15. 5.2014 [cit. 2017-05-02]. Available from www: <http://www.fbm.htwkleipzig.de/index.php?id=9178 $>$.

KIRSCH, Otakar. Vysokoškolská výuka muzeologie $\mathrm{v}$ Brně $\mathrm{v}$ době normalizace a nástupu demokratického režimu. Museologica Brunensia [online]. 2014, vol. 3, no. 2, pp. 12-20 [cit. 2017-0202]. Available from www: <https:// digilib.phil.muni.cz/bitstream/ handle/11222.digilib/133107/2_ MuseologicaBrunensia_3-2014-2_4. pdf? sequence $=1>$. ISSN 2464-5362. KIRSCH, Otakar and Lucie JAGOŠOVÁ. Vývoj Lektorátu muzejnictví 1922-1951. Devadesát let od počátků univerzitního vzdělávání muzejníků v českých zemích. Muzeum: muzejní a vlastivědná práce, 2013, vol. 51, no. 1, pp. 3-16. ISSN 1803$-0386$.

LORENTE, Jesús Pedro. The development of museum studies in universities: from technical training to critical museology. Museum management and curatorship [online]. 2012, vol. 27, no. 3, pp. 237-252 [cit. 2017-02-02]. Available from www: <http://www.academia edu/1846608/The_development of_museum_studies_in_universities_ from_technical_training_to_critical_ museology >. ISSN 1872-9185.

Masaryk University Information System [online]. [cit. 2017-02-02]. Available from www: $<$ https://is.muni. $\mathrm{cz} /$ ?lang $=\mathrm{en}>$.

MRÁZOVÁ, Lenka. Remarks on the role of Z. Z. Stránský in conceptual development of the curriculum of Brno museology.
Museologica Brunensia [online]. 2016, vol. 5, no. 2, pp. 65-73 [cit. 2017-02-02]. Available from www: <https:// digilib.phil.muni.cz/bitstream/ handle/11222.digilib/136265/2_ MuseologicaBrunensia_5-2016-2_9. pdf? sequence $=1>$. ISSN 2464-5362.

MRÁZOVÁ, Lenka and Lucie JAGOŠOVÁ. Contentual changes in the curriculum of the Brno Chair of Museology in 19642014. In UNESCO Chair of Museology and World Heritage [online]. [cit. 2017-05-02]. Available from www: $<$ http://www. phil.muni.cz/wune/home/publikace/ clanky/view?set_language $=e n>$.

MÜLLER-STRATEN, Christian. The contribution of Zbyněk Stránský to museology and contribution of the Brno museology school. In Muzealizace $v$ soudobé společnosti a poslání muzeologie/Musealization in contemporary society and role of museology: Sborník ze sympozia s mezinárodní účastí pořádaného při př́ležitosti životního jubilea tvůrce brněnské muzeologické školy Zbyňka Z. Stránského/Anthology from symposium with foreign participation in the occasion of anniversary of the founder of the Brno museology school Zbyněk Z. Stránský. Praha: Asociace muzeí a galerií České republiky, 2008, pp. 27-35.

RUTAR, Václav. Vznik, vývoj a práce externí katedry muzeologie v Brně v letech 1963-1969. Museologica Brunensia [online]. 2014, vol. 3, no. 2, pp. 4-11 [cit. 2017-02-02]. Available from www: <https://digilib.phil.muni.cz/bitstream/ handle/11222.digilib/133106/2 MuseologicaBrunensia_3-2014-2_3. pdf?sequence $=1>$. ISSN 2464-5362.

SCHNEIDER, Evžen. Specifické vzdělávání muzejních pracovníků a jeho usoustavnění v ČSR. Muzeologické sešity: Supplementum 3, 1985, pp. 85-126.

STRÁNSKÝ, Zbyněk Z. Brno: education in museology: on the 10. anniversary of the foundation of the museological department of the Philos. fac. of the J. E. Purkyner University in Brno. Brno: J. E. Purkyně University, 1974.

STRÁNSKÝ, Zbyněk Z. Vzdělávání pro muzejní profesi. In Teorie a praxe 2007: Sborník z mezinárodního semináře Setkání vyučujicích muzeologie na vysokých školách v České republice a na Slovensku.
Brno: Technické muzeum v Brně, 2008, pp. 11-16. ISBN 978-80-86413-51-8.

WALZ, Markus. Theory and Praxeology of Museology: On the Current Ascendancy of Special Museologies in Germany. Museologica Brunensia [online]. 2015, vol. 4, no. 2, pp. 20-27 [cit. 2017-0202]. Available from www: <https:// digilib.phil.muni.cz/bitstream/ handle/11222.digilib/134744/2_ MuseologicaBrunensia_4-2015-2_6. pdf?sequence $=1>$. ISSN 2464-5362. 


\section{LUCIE JAGOŠOVÁ}

Ústav archeologie a muzeologie Oddělení muzeologie, Filozofická fakulta, Masarykova univerzita, Brno, Česká republika

jagosova@phil.muni.cz

She studied cultural heritage management (Vocational School of Information and Library Services, Brno), and graduated in museology and pedagogy (Masaryk University, Brno). She is an instructor at the Department of Archaeology and Museology of the Faculty of Arts of Masaryk University, lectures and publishes on the subject of museum pedagogy and psychology, and is the co-author of the publications Museum Education. Methodological and Didactical Aspects of Museum Education (2010); The Basics of Museum Pedagogy. Study texts (2014); Museum Professions and the Public 1. Outline of the history and present of the relationship between museums and their audiences (2016). She participates in creating the programme of the course "The Basics of Museum Pedagogy" of the Methodical Centre of Museum Pedagogy, and works in the Public Relations and Museum Pedagogy Committee within the Association of Museums and Galleries of the Czech Republic (since 2015 as vicechairperson).

Vystudovala obory správa kulturních památek (Vyšší odborná škola informačních a knihovnických služeb, Brno), muzeologie, pedagogika (Masarykova univerzita, Brno). Působí na Ústavu archeologie a muzeologie Filozofické fakulty Masarykovy univerzity jako asistentka. Přednáší a publikuje k problematice muzejní pedagogiky a psychologie. Je spoluautorkou publikací Muzejní pedagogika. Metodologické a didaktické aspekty muzejní edukace (2010), Základy muzejní pedagogiky. Studijní texty (2014), Muzejní profese a veřejnost 1. Nástin historie a současnosti vzájemných vztahů muzeí a jejich publika (2016). Lektorsky se podílí na kurzu Základy muzejní pedago- giky Metodického centra muzejní pedagogiky a působí v Komisi pro práci s veřejností a muzejní pedagogiku při Asociaci muzeí a galerií České republiky (od roku 2015 jako místopředsedkyně).

\section{OTAKAR KIRSCH}

Ústav archeologie a muzeologie Oddělení muzeologie, Filozofická

fakulta, Masarykova univerzita, Brno, Česká republika

o.kirsch@seznam.cz

In 2001 he completed his master's degree in religious studies, history and museology at the Faculty of Arts of the Masaryk University in Brno (FF MU). Since 2005 he has been fellow (since 2009 lecturer) in the Museology Section of the Department of Archaeology and Museology FF MU. In 2009 he defended his doctoral thesis in the field of Historical sciences at the Department of History FF MU. The treatise dealing with German museums in Moravia was published in a modified form in 2014 under the title Forgotten memory bearers. German museum work in Moravia. He is the co-author of the publication Museum Professions and the Public 1. Outline of the history and present of the relationship between museums and their audiences (2016). He specialises in the history of museums and museology, and museum documentation.

$\mathrm{V}$ roce 2001 dokončil magisterské studium religionistiky, historie a muzeologie na Filozofické fakultě Masarykovy univerzity v Brně (FF MU). Od roku 2005 působí na Oddělení Muzeologie Ústavu archeologie a muzeologie FF MU (od roku 2009 jako odborný asistent). V roce 2009 obhájil disertační práci v oboru Historických věd na Historickém ústavu FF MU. Vědecká práce o německých muzeích na Moravě byla publikována $\mathrm{v}$ upravené podobě $\mathrm{v}$ roce 2014 jako monografie $s$ názvem (Po)zapomenutí nositelé paměti. Německé muzejnictví na Moravě.
Je spoluautorem publikace Muzejní profese a veřejnost 1 . Nástin historie a současnosti vzájemných vztahů muzeí a jejich publika (2016). Specializuje se na vývoj muzejního fenoménu a muzeologie a muzejní dokumentaci. 